\title{
Congenital imperforate hymen
}

\section{Omar Laghzaoui}

Gynécologie Obstetrique, Hôpital Militaire d'Instruction Meknès Maroc, Meknès, Morocco

\section{Correspondence to} Professor Omar Laghzaoui, omar120162@yahoo.fr

Accepted 20 April 2016

\section{DESCRIPTION}

A 16-year-old girl was referred to our gynaecology service, reporting of cyclic pelvic pain and primary amenorrhoea. The medical history had

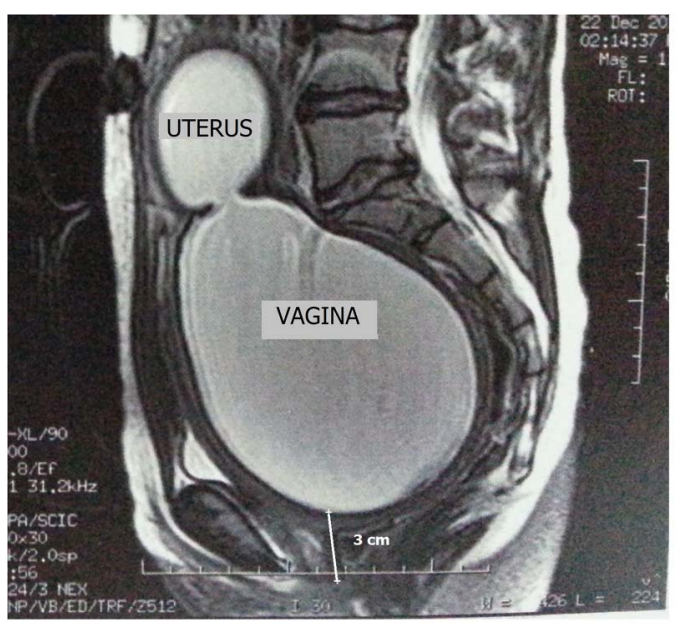

Figure 1 Interference reflection microscopy (IRM)imperforate hymen. begun 4 years earlier with pelvic pain getting worse over time, disturbing her studies. Physical examination revealed a mass of 14 weeks' gravid uterus. The patient's secondary sexual characters were well developed (breasts, pubic and underarm hair). Examination of the vulva revealed an imperforate hymen. Digital examination of the rectum perceived a tense and compressible pelvic mass. The patient weighed $55 \mathrm{~kg}$ and was $165 \mathrm{~cm}$ tall, her blood pressure was 100/ $50 \mathrm{~mm} \mathrm{Hg}$ and rate $76 \mathrm{bpm}$, her temperature was normal, $37^{\circ} \mathrm{C}$.

Transabdominal ultrasonography and MRI confirmed the diagnosis: the imperforate hymen was $3 \mathrm{~cm}$ thick, haematocolpos measured $12 \times 9.5 \mathrm{~cm}$ and haematometra was noted (figure 1). This malformation was classified as U0.C0.V3 according to the European Society of Human Reproduction and Embryology classification of congenital malformations.

We opted for a large excision of the hymenbecause the membrane's thickness measured $3 \mathrm{~cm}$ -and a plasty using the vaginal tissue to prevent hymen restenosis (figure 2).

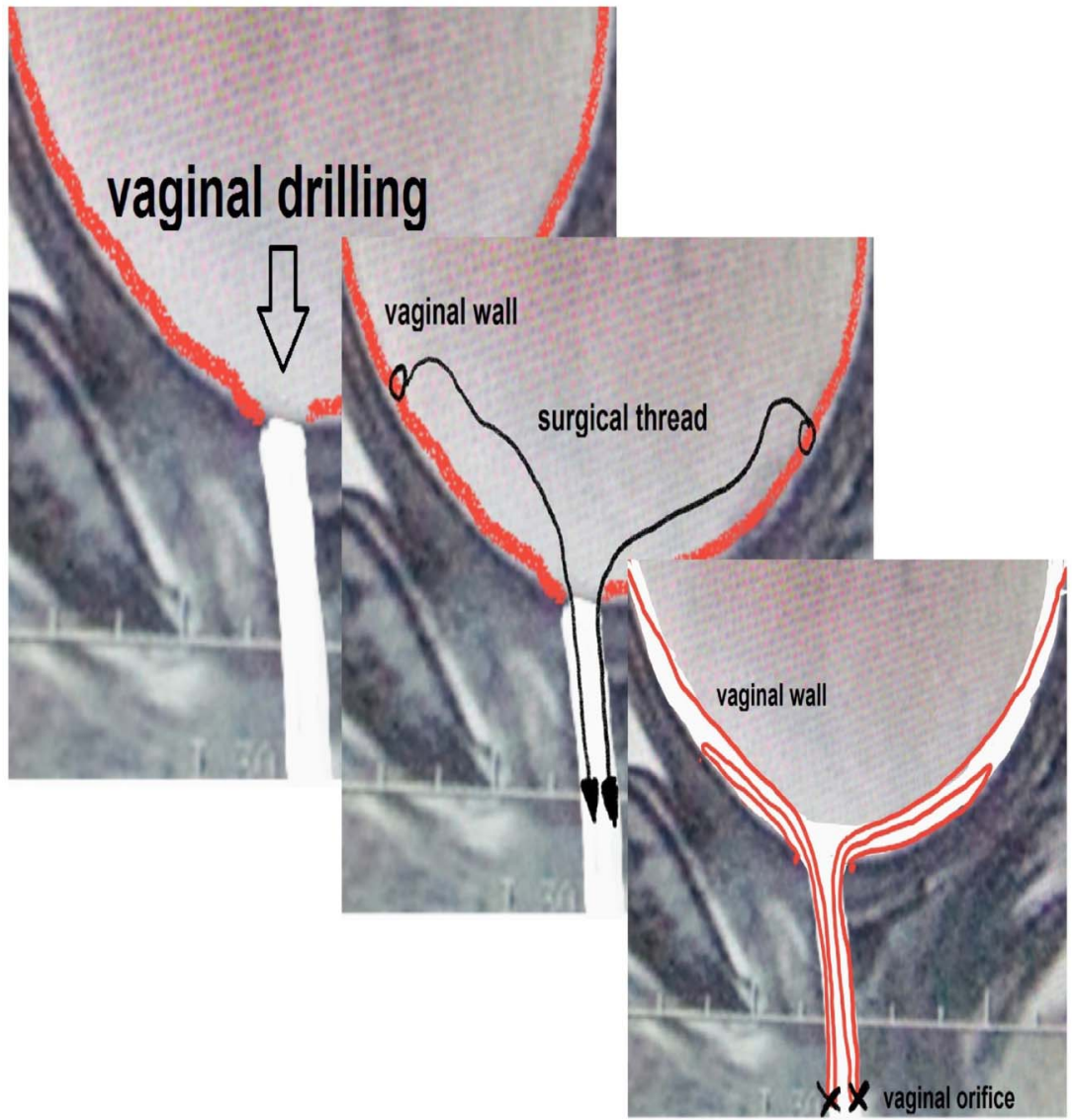

Figure 2 Schematic representation of vaginoplasty. 

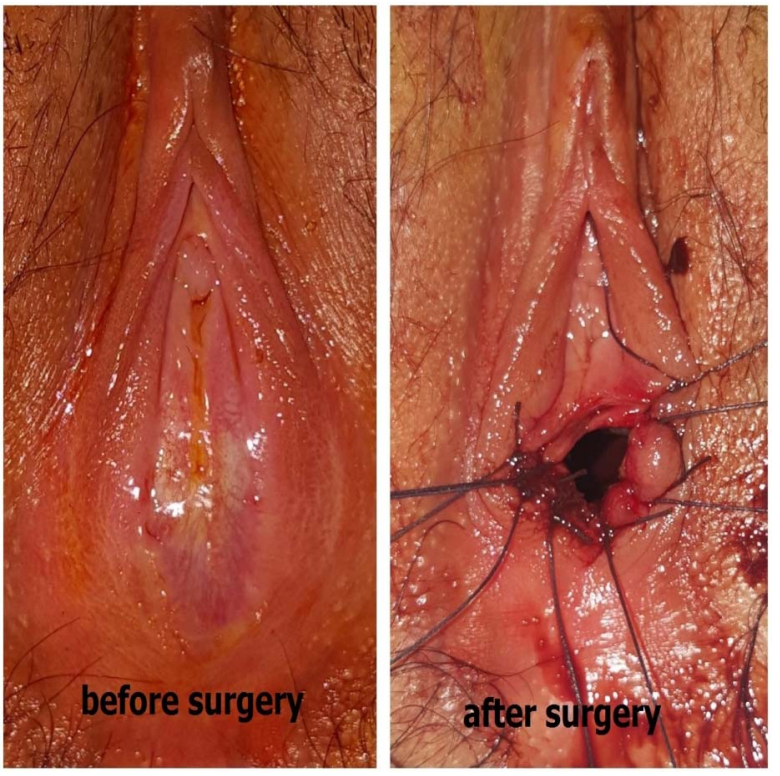

Figure 3 Vaginoplasty before and after surgery.

A circular excision of the hymen was accomplished using advanced needle cautery, which led to the flow of $2 \mathrm{~L}$ of the material confined beyond the hymen. The lower segment of the vaginal wall was fixed to the introitus with surgical sutures (figures 3).

Postoperative analgaesia was realised with lidocaine cream and ice packs. The surgical result was good and the patient had a normal menstruation cycle without pain.

\section{Learning points}

- Imperforate hymen occurs in $~ 1 / 1000$ newborn girls. It is the most common obstructive anomaly of the female reproductive tract. It must be diagnosed at birth by the paediatrician; otherwise, it presents complications at puberty: blood collection inside the vaginal cavity, amenorrhoea and pelvic pain or a risk of secondary

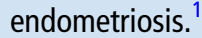

- Transabdominal ultrasonography is sufficient for imperforate hymen diagnosis but MRI provides more details on hymen thickness enabling choice of the appropriate surgical technique: a thick hymen needs surgical resection; a thin hymen only needs a vertical incision. ${ }^{1} 2$

- Fixing the vaginal wall to the introitus avoids restenosis and gives a complication-free postoperation result. ${ }^{2} 3$

Competing interests None declared.

Patient consent Obtained.

Provenance and peer review Not commissioned; externally peer reviewed.

\section{REFERENCES}

1 Nielsen V, Vyrdal C. Imperforate hymen can cause abdominal pain and primary amenorrhoea. Ugeskr Laeger 2013;175:1500-1.

2 Ossman AM, El-Masry YI, El-NAmoury MM, et al. Spontaneous reformation of imperforate hymen after repeated hymenectomy. J Pediatr Adolesc Gynecol 2016; S1083-3188:00160-1.

3 Juth N, Tännsjö T, Hansson SO, et al. Honour-related threats and human rights: a qualitative study of Swedish healthcare providers' attitudes towards young women requesting a virginity certificate or hymen reconstruction. Eur J Contracept Reprod Health Care 2013;18:451-9.

Copyright 2016 BMJ Publishing Group. All rights reserved. For permission to reuse any of this content visit

http://group.bmj.com/group/rights-licensing/permissions.

BMJ Case Report Fellows may re-use this article for personal use and teaching without any further permission.

Become a Fellow of BMJ Case Reports today and you can:

- Submit as many cases as you like

- Enjoy fast sympathetic peer review and rapid publication of accepted articles

- Access all the published articles

- Re-use any of the published material for personal use and teaching without further permission

For information on Institutional Fellowships contact consortiasales@bmjgroup.com

Visit casereports.bmj.com for more articles like this and to become a Fellow 